\title{
EFFECTS OF FEEDING FAT ON LACTATION PERFORMANCE OF THE LABORATORY MOUSE, Mus musculus
}

\author{
J. K. KAGYA-AGYEMANG, C. HAMBLY, E. KRÓL AND J. R. SPEAKMAN
}

(Received 26 March, 2009; Revision Accepted 12 October, 2009)

\begin{abstract}
Laboratory mice (strain MF1) were used to investigate the effects of dietary fat intake on lactation performance. The specific dynamic action (SDA) for high fat (HF), medium fat (MF) and a low fat (LF) diets was measured using open-flow respirometry at $4.5 \%, 3.9 \%$ and $6.1 \%$, respectively. The same three diets were fed ad libitum to mice between days 4 and 18 of lactation. Mice fed HF, MF and LF diets reached plateau in their daily food intake at $14.95 \pm 1.14 \mathrm{~g} \mathrm{day}^{-1}, 16.30 \pm 0.61 \mathrm{~g} \mathrm{day}^{-1}$ and $16.57 \pm 0.26 \mathrm{~g}^{-1}{ }^{-1}$, respectively between days $12-17$ of lactation. At weaning, litters from HF and MF-fed mice were significantly heavier than pups on LF diet. This was because the HF and MF-fed mice not only consumed more energy at peak lactation but also delivered more milk energy to their pups than the LF-fed mice. Evidence suggested that the positive effects of feeding fat to mice were in part due to the low SDA and probably low heat production for milk synthesis. Probably, the ability of the HF and MF-fed mice to directly transfer absorbed fat into the milk might have reduced the heat production of lactogenesis. The HF and MF diets had beneficial effects on lactation because they increased the capacity of mice to generate milk more efficiently and wean heavier offspring than mice fed LF diet. The daily energy expenditure (DEE) of mice in the three dietary groups was fixed.
\end{abstract}

KEY WORDS: Laboratory mouse, dietary fat, specific dynamic action, doubly labelled water, daily energy expenditure, milk energy output, reproductive performance

\section{INTRODUCTION}

Since energy is a key resource, limits on the availability and expenditure have a potentially profound effect on the evolution of many morphological and behavioural traits (Stenseth et al., 1980; Speakman and McQueenie, 1996). The sustained maximal rate of energy intake (SusEl) is an important factor that imposes an upper limit on animal performance that depend critically on energy, such as reproductive output (Hammond and Diamond, 1997; Speakman, 2000; Johnson et al., 2001a; Bacigalupe and Bozinvic, 2002; Krol and Speakman, 2003a; Król and Speakman, 2003 b; Krol et al., 2007) and thermoregulatory capabilities, which may define the global distribution limits of endotherms (Bozinovic and Rosenmann,1989; Bacigalupe and Bozinovic, 2002). SusEl is the maximum rate of energy intake that animals can sustain over protracted period of days to weeks so that energy demands are fuelled only by food intake (Speakman and $\mathrm{Krol}, 2005 \mathrm{a})$. The question therefore arises as to which factors influence the SusEl. SusEl may impose a limit on maximal rates of energy expenditure during reproduction.

Limits on SusEl are likely to be particularly important during peak lactation, which is the time of greatest energy demand on female mammals (Kenegy et al., 1990; Hammond and Diamond, 1994; Hammond et al., 1996; Speakman and McQueenie, 1996; Hammond and Kristan, 2000; Johnson and Speakman,
2001; Johnson et al., 2001a, b; Krol and Speakman, 2003a; Krol et al., 2007). Limitations on SusEl during lactation may determine the total investment that mammals can make in their offspring and may therefore define maximum litter and offspring sizes, which are important life history traits (Johnson et al., 2001; Król and Speakman, 2003a, b; Król et al., 2007).

A diet high in dietary fat typically promotes greater calorie intake and weight gain than a diet having low fat content (Averette, et al. 1999; Kagya-Agyemang, 2008). Feeding lactating rats high fat diet has been reported to result in diminished mammary gland lipogenesis and in reduced growth rates and increased mortality of pups (Angus and Williams, 1980; Rolls et al. 1984). Other studies have reported that pups of dams fed high fat diet grew better than did controls (Grigor and Warren, 1980; Del Prado et al. 1997; Loh et al. 2002; Kagya-Agyemang, 2008). These contradictory results might be due to differences in the experimental designs. The proportion of fat in the high fat diets differed among the studies, ranging between 10 and $60 \mathrm{~g}$ fat $/ 100 \mathrm{~g}$ diet (Del Prado et al. 1997). Milk composition can be altered by diet to some extent. Lactose and milk protein concentrations generally are not subjected to major changes by modifying diet. However, milk fat can be altered by dietary fat level (Loh et al. 2002). There is the need to know more about fat inclusion in the maternal diet since the nutritional value of milk produced during lactation may be very important for improving preweaning growth and development of mammals. It has

J. K. Kagya-Agyemang ${ }^{1,2}$, ${ }^{1}$ School of Biological Sciences, University of Aberdeen, Aberdeen, AB24 2TZ, UK

${ }^{2}$ Dept. of Animal Sci. Education, Univ. of Education, Winneba, P.O. Box 40, Mampong-Ashanti, Ghana

C. Hambly, School of Biological Sciences, University of Aberdeen, Aberdeen, AB24 2TZ, UK

E. Król, School of Biological Sciences, University of Aberdeen, Aberdeen, AB24 2TZ, UK

J. R. Speakman, School of Biological Sciences, University of Aberdeen, Aberdeen, AB24 2TZ, UK 
been shown that the nutritional status of the dam during the gestational and lactational periods is essential to normal growth and development of the offspring (Rolls et al. 1984). The ingestion of a high fat diet during gestation leads to a higher body weight gain by dams (Rolls et al. 1984) but dams fed fat during lactation have their food intake constrained because their heat production is already maximal Adels and Leon, 1986; Król and Speakman, 2003a, b).

Diets with different macronutrient contents have different specific dynamic action (SDA). It is well established that fat has lower SDA than protein and carbohydrate (Kriss et al., 1934; Gawecki and Jeszka, 1978; Kagya-Agyemang, 2008). Therefore, it would be predicted that mice fed a high/medium fat diet should be able to consume more food at peak lactation with positive consequences for milk production and growth of their offspring.

In the present study, we investigated the effects of maternal fat intake on energy expenditure and lactation performance. This work could explain the limits to fat intake during lactation in mice.

\section{MATERIALS AND METHODS}

\section{Animals and experimental protocol}

Sixty virgin female mice (Mus musculus L.: out bred MF1) aged 9-10 weeks old were used in this study (Harlan UK Limited, Shaw's Farm, England). The animals were individually housed in cages $(44 \mathrm{~cm} \times 12$ $\mathrm{cm} \times 13 \mathrm{~cm}$ ) with sawdust. Rat and mouse breeder and grower diet $(15.60 \mathrm{~kJ} / \mathrm{g}$ gross energy, $18.80 \%$ crude protein, $60.30 \%$ carbohydrate, $3.40 \%$ crude oil, $3.7 \%$ crude fibre and $3.80 \%$ ash - all values calculated to nominal $10 \%$ moisture content, Special Diets Services, BP Nutrition, Witham, UK) and water were supplied ad libitum. The environment was regulated at $21^{\circ} \mathrm{C}$ (range 20 to $22^{\circ} \mathrm{C}$ ) on a $12 \mathrm{~L}: 12 \mathrm{D}$ photoperiod with lights on at 07:00 h. After acclimation to the experimental conditions, baseline measurement of body mass was used to allocate mice into three experimental groups with 20 animals per group. Each female was paired with a male for 11 days. After the males had been removed, female body mass and food remaining in each hopper were weighed each morning between 08:00 $\mathrm{h}$ and 10:00 h, using a (Mettler Toledo, Switzerland) top-pan balance $( \pm 0.01 \mathrm{~g})$. Food intake was calculated from the difference between the amount of food provided and that left in the hopper.

On the day of parturition (day 0 of lactation), no measurements were made on the lactating mothers and their pups. From days 1 to 18 of lactation maternal body mass, litter size, litter mass and pup mortality were recorded daily. On days 2 to 3 of lactation, mothers from each experimental group were presented with either high fat (HF), medium fat (MF) or low fat (LF) diet while still supplied with standard rodent chow ad libitum. The diets used were HF, MF and LF diets (Research Diets, New Brunswick, NJ, U.S.A). The composition of experimental diets is shown in Table1. From day 4 onwards, the animals were switched from the chow diet to HF, MF or LF diet exclusively. Maternal food intake was recorded between days 5-18 of lactation. All animals were maintained in accordance with the United
Kingdom Home Office Animals (Scientific procedures) Act 1986.

\section{Doubly labelled water measurements}

The doubly labelled water (DLW) method was used to measure daily energy expenditure (DEE) from the elimination rates of ${ }^{2} \mathrm{H}$ (deuterium) and ${ }^{18} \mathrm{O}$ in lactating females during peak lactation. The total water turnover $\left(\mathrm{rH}_{2} \mathrm{O}\right)$ from the elimination rates of ${ }^{2} \mathrm{H}$ in lactating females was also calculated. Measures of DEE were made to determine the milk energy output (MEO) from the difference between metabolizable energy intake and DEE (Król and Speakman, 2003b).

The DLW measurements were conducted on 56 lactating females ( $\mathrm{HF}, \mathrm{N}=19, \mathrm{MF}, \mathrm{N}=19$ and $\mathrm{LF} \mathrm{N}=18$ ). On day 16 of lactation (between 8:00h and 11:00h) individual mice were weighed to $\pm 0.01 \mathrm{~g}$ using a balance (Mettler Toledo, Switzerland) and labelled with an intraperitoneal injection of approximately $0.2 \mathrm{~g}$ of water containing enriched ${ }^{2} \mathrm{H}$ (36.3 atoms\%) and ${ }^{18} \mathrm{O}$ ( 59.9 atoms\%). The syringe used to inject the DLW was weighed $( \pm 0.0001 \mathrm{~g}$; Ohaus Analytical Plus, Brookylin, USA) immediately before and after the injection to provide an accurate measurement of the amount of the isotope injected. Mice were placed in their cages during the $1 \mathrm{~h}$ equilibration period (Speakman, 1997). An initial 30-80 $\mu$ l blood sample was collected by tail tipping $1 \mathrm{~h}$ after the injection, which was the time generally assumed to be required for the isotope to reach equilibrium (Król and Speakman, 1999). Blood samples were immediately flame-sealed into pre-calibrated $50 \mu \mathrm{l}$ pipettes and stored at $4{ }^{\circ} \mathrm{C}$ until analysis. A final blood sample was collected approximately $48 \mathrm{~h}$ after the initial blood sample was collected to estimate isotope elimination rates. This was done after the body mass of each animal was measured.

Samples of blood in capillaries were vacuumdistilled (Nagy, 1983) and water from the resulting distillate was used to produce $\mathrm{CO}_{2}$ (Speakman et al., 1990) and $\mathrm{H}_{2}$ (Speakman and Król, 2005b). Gas source isotope ratio mass spectrometer was used to analyse the isotope ratios of ${ }^{18} \mathrm{O}:{ }^{16} \mathrm{O}$ and ${ }^{2} \mathrm{H}:{ }^{1} \mathrm{H}$. The samples were run alongside high enrichment standards that were used to correct the raw data to these standards.

For each lactating mouse, initial ${ }^{2} \mathrm{H}$ and ${ }^{18} \mathrm{O}$ dilution spaces were calculated by the intercept method (Coward and Prentice, 1985; Speakman and Król, $2005 \mathrm{~b}$ ) and then converted to mass assuming a molecular mass of body water of 18.020 and expressed as a percentage of body mass before injection. The intercept method was used since the actual body water pool estimated by desiccation using the intercept method was more accurate than the plateau method (Speakman and Król, 2005b). The final ${ }^{2} \mathrm{H}$ and ${ }^{18} \mathrm{O}$ dilution spaces were inferred from the final body mass, assuming the same percentage of body mass as measured for the initial dilution spaces. The isotope elimination rate (k) was calculated following Nagy (1975). For calculation of DEE based on $\mathrm{CO}_{2}$ production, single pool model equation 7.17 (Speakman, 1997) was used. Energy equivalents of rates of $\mathrm{CO}_{2}$ production were calculated using a conversion factor of $24.03 \mathrm{~J} \mathrm{ml}^{-1} \mathrm{CO}_{2}$, derived from the Weir equation (Weir, 1949). 
Female total water turnover $\left(\mathrm{rH}_{2} \mathrm{O}\right)$ was calculated by multiplying the fractional turnover rate by the total body water (TBW). It was assumed that $25 \%$ of the water leaving the body was fractionated (Speakman, 1997). Therefore, a fractionation factor of 0.9366 was applied for deuterium turnover (Speakman, 1997). This approach assumes that rates of water influx and efflux are constant, so $\mathrm{rH}_{2} \mathrm{O}=$ total water influx $=$ total water efflux (Nagy and Costa, 1980).

\section{Milk energy output}

Milk energy output (MEO) was evaluated as the difference between metabolizable energy intake (MEI) and daily energy expenditure (Król and Speakman, 2003b).

\section{Statistics}

The differences in baseline and pregnancy data between the three dietary groups for body mass and food intake were analysed using repeated measures analysis of variance (ANOVA). The significance of change in body mass and food intake over time was assessed by general linear modeling (GLM). Significant differences between days and diets were detected using the Tukey test. Asymptotic food intake across the three dietary treatment groups in late lactation was compared using ANOVA. The asymptotic food intake in late lactation was defined as the period during which no significant differences in food intake between days were detected. Least squares regression analysis was used to examine the relationship between DEE and maternal body mass, total water turnover and maternal body mass, milk energy output (MEO) and litter size, and litter growth and MEO. Data are represented as means \pm standard deviation (SD). Unless stated otherwise, $\mathrm{N}=$ number of animals. All statistical analyses were performed using Minitab for Windows (version 14; Minitab Inc., State College, PA, USA; Ryan et al., 1985). All statistical significance were determined at $P<0.05$.

Table 1: Composition of macronutrient diets

\begin{tabular}{|l|l|l|l|}
\hline Diet code & D12492 & D12451 & D12450B \\
\hline Diet & High fat & Medium fat & Low fat \\
\hline & Kcal & Kcal & kcal \\
\hline Fat & 60 & 45 & 10 \\
\hline Carbohydrate & 20 & 35 & 70 \\
\hline Protein & 20 & 20 & 20 \\
\hline Total & 100 & 100 & 100 \\
\hline Ingredients (g/kg diet) & & & \\
\hline Casein & 200 & 200 & 200 \\
\hline L-cystine & 3 & 3 & 3 \\
\hline Corn starch & 0 & 72.8 & 315 \\
\hline Maltodextrin & 125 & 100 & 35 \\
\hline Sucrose & 68.8 & 172.8 & 350 \\
\hline Cellulose & 50 & 50 & 50 \\
\hline Soya oil & 25 & 25 & 25 \\
\hline Lard & 245 & 177.5 & 20 \\
\hline Mineral mix & 10 & 10 & 10 \\
\hline Dicalcium phosphate & 13 & 13 & 13 \\
\hline Calcium carbonate & 5.5 & 5.5 & 5.5 \\
\hline Potassium citrate & 16.5 & 16.5 & 16.5 \\
\hline Vitamin mix & 10 & 10 & 10 \\
\hline Choline bitartrate & 2 & 2 & 2 \\
\hline Gross energy (kJ g $\left.{ }^{-1}\right)$ & 19.90 & 19.89 & 19.89 \\
\hline
\end{tabular}

Source: Research Diets, New Brunswick, NJ, U.S.A

\section{RESULTS}

\section{Maternal body mass}

There was no significant difference between the body mass of HF females $(29.51 \pm 1.29 \mathrm{~g}, \mathrm{~N}=20)$, MF females $(29.52 \pm 1.33 \mathrm{~g}, \mathrm{~N}=20)$ and LF females $\left(29.52 \pm 1.42 \mathrm{~g}, \mathrm{~N}=20\right.$; ANOVA: $\left.\mathrm{F}_{2,57}=0.01, \mathrm{P}=0.999\right)$ before mating. Body mass increased significantly during days 12-21 of pregnancy in HF females (ANOVA: $F_{9}$, ${ }_{180}=29.94, P<0.001, N=19$ ), $M F$ females (ANOVA: $F_{9}$, ${ }_{180}=47.89, P<0.001, N=19$ ) and $L F$ females (ANOVA: $F_{9}$, $170=39.14, \quad P<0.001, N=18$ ) reaching a peak of , $53.96 \pm 4.18 \mathrm{~g}, 55.83 \pm 5.06 \mathrm{~g}$ and $56.28 \pm 5.24 \mathrm{~g}$, for HF, MF and LF females, respectively just before parturition (Figure 1).
Between days 1-4 of lactation the body mass of female mice in each group increased. Maternal body mass of HF, MF and LF females did not show any significant difference (ANOVA: $F_{2}, 221=0.85, P=0.430$ ) and averaged $41.39 \pm 3.82 \mathrm{~g}, 41.15 \pm 2.04 \mathrm{~g}$, and $41.79 \pm 3.05 \mathrm{~g}$ on the day after parturition and increased to $42.67 \pm 3.18 \mathrm{~g}, 42.36 \pm 2.55 \mathrm{~g}$, and $42.39 \pm 3.25 \mathrm{~g}$ on day 4 , respectively for HF, MF and LF mice. The trend of change in body mass of $\mathrm{HF}, \mathrm{MF}$ and $\mathrm{HC}$ mothers followed a similar pattern (Figure 1). There was a highly significant effect of day of lactation (GLM: $F_{13,742}=4.32$, $P<0.001$ ) on maternal body mass and there was a highly significant effect of diet (GLM: $\left.F_{13,742}=5.95, P<0.005\right)$. However, there was no significant diet by day interaction (GLM: $F_{13, \quad 742}=0.23, \quad P=1000$ ). All Tukey pairwise comparisons among levels of diet showed that the LF- 
fed mice were significantly heavier $(P<0.05)$ than $\mathrm{HF}$ and MF-fed mothers between days 5-18 of lactation.
The body mass of HF and MF-fed mice showed no significant difference $(\mathrm{P}>0.05)$.

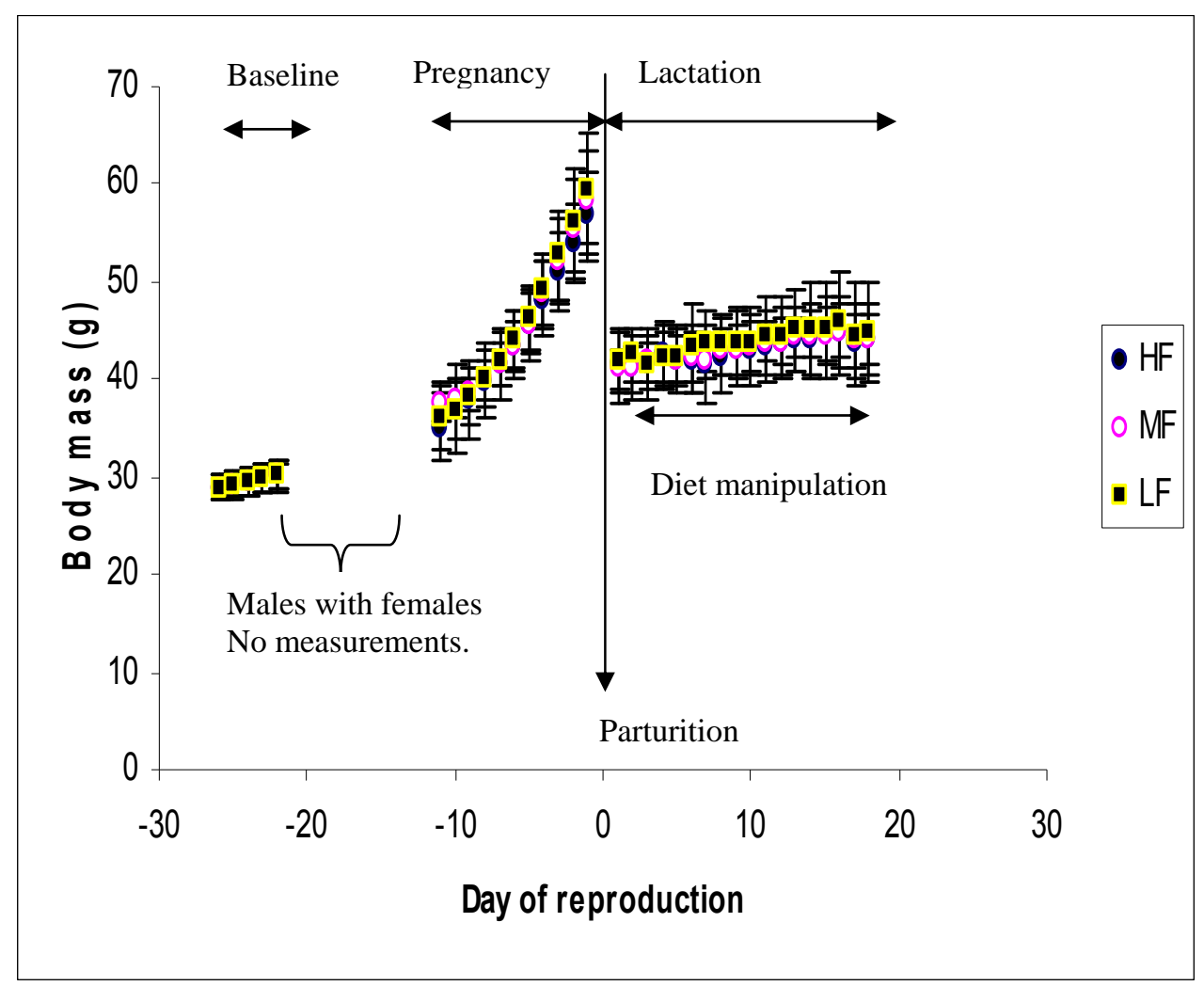

Figure 1: Mean body mass of female mice throughout baseline, pregnancy and lactation. Day 0 was parturition. Diet manipulation started on day 4 of lactation. Mice were fed high fat (HF), medium fat (MF), and low fat (LF) diets. Maternal body mass was measured between days 1-18 of lactation. Error bars represent 1 sd of the mean.

\section{Food intake}

The food intake of female mice in the three dietary groups was not significantly different before mating (ANOVA: $F_{2,9}=0.01, P=0.999$ ). The animals consumed a mean of $5.28 \pm 0.51 \mathrm{~g}$ day $^{-1}, 5.28 \pm 0.27 \mathrm{~g}$ day $^{-1}$ and $5.27 \pm 0.36 \mathrm{~g}$ day $^{-1}$ for HF, MF and LF females, respectively. Food intake increased significantly during days $12-21$ of pregnancy in $\mathrm{HF}$ (ANOVA: $F_{9}, 180=10.30, P<0.001$ ), MF (ANOVA: $F_{9}$, ${ }_{180}=15.11, P<0.001$ ) and $L F$ females (ANOVA: $F_{9}$, $170=9.44, P<0.001$ ) reaching a maximum of $8.16 \pm 1.15 \mathrm{~g}$, $8.04 \pm 1.13 \mathrm{~g}$ and $8.49 \pm 1.09 \mathrm{~g}$ before decreasing to $6.94 \pm 0.40 \mathrm{~g}, 6.92 \pm 0.59 \mathrm{~g}$ and $7.20 \pm 0.57 \mathrm{~g}$ for HF, MF and LF females, respectively on the day before parturition (Figure 2).

Diet manipulation started on day 4 of lactation, so there was no food intake data for days 1-4 of lactation when animals were fed a mix of rodent chow and the target diets. There was a significant increase in food intake between days 5-11 of lactation in females fed HF diet (ANOVA: $F_{6,126}=4,42, P<0.001$ ), MF diet (ANOVA: $F_{6,126}=3.54, P<0.001$ ) and those fed $L F$ diet (ANOVA: $F_{6, \quad 119}=8.18, \quad P<0.001$ ) from $10.45 \pm 1.86 \mathrm{~g}$, $12.27 \pm 2.26 \mathrm{~g}$ and $12.43 \pm 2.68 \mathrm{~g}$ on the day after the animals were fed macronutrient diets exclusively to $13.20 \pm 2.60 \mathrm{~g}, 14.89 \pm 2.39 \mathrm{~g}$ and $16.33 \pm 1.88 \mathrm{~g}$ on day 11 , respectively. Over the next 6 days (days 12-17), daily food intake remained constant (ANOVA: $P>0.05$ ) at an average of $14.95 \pm 1.14 \mathrm{~g}$ day $^{-1}, 16.30 \pm 0.61 \mathrm{~g}$ day $^{-1}$ and $16.57 \pm 0.26 \mathrm{~g}$ day $^{-1}$ for mice fed HF, MF and LF diets, respectively. The food intake averaged over these 6 days was termed the asymptotic daily food intake (Figure 2). The corresponding asymptotic gross energy intakes were $345.40 \pm 26.41 \mathrm{~kJ}^{-1} \mathrm{yy}^{-1}, 373.04 \pm 13.92 \mathrm{~kJ}$ day $^{-1}$ and $294.98 \pm 4.64 \mathrm{~kJ}$ day $^{-1}$ (equivalent to digestible energy intakes of $306.52 \pm 25.03 \mathrm{~kJ}, 340.52 \pm 13.49 \mathrm{~kJ}$ and $266.67 \pm 4.45 \mathrm{~kJ}$ ) for mice fed HF, MF and LF diets, respectively.

On day 18 of lactation, the daily food intake increased above the asymptotic level (Figure 2). This might be due to the fact that the pups started feeding directly on the food in the hoppers on this day. Over all, there was a highly significant effect of day of lactation (GLM: $F_{13,742}=21.24, P<0.001$ ) on maternal food intake and a highly significant effect of diet (GLM: $F_{13}$, $742=36.05, P<0.001)$ on maternal food intake between days 5-18 of lactation. All Tukey pairwise comparisons among levels of diet showed that the mass of food intake of LF females was significantly higher $(P<0.05)$ than that of HF and MF mothers between days 5-18 of lactation. The food intake of $\mathrm{HF}$ and MF-fed mice showed no significant difference $(P>0.05)$. There was no significant interaction effect (GLM: $F_{13},{ }_{742}=0.01$, $P=1.000$ ) on maternal food intake during lactation. 


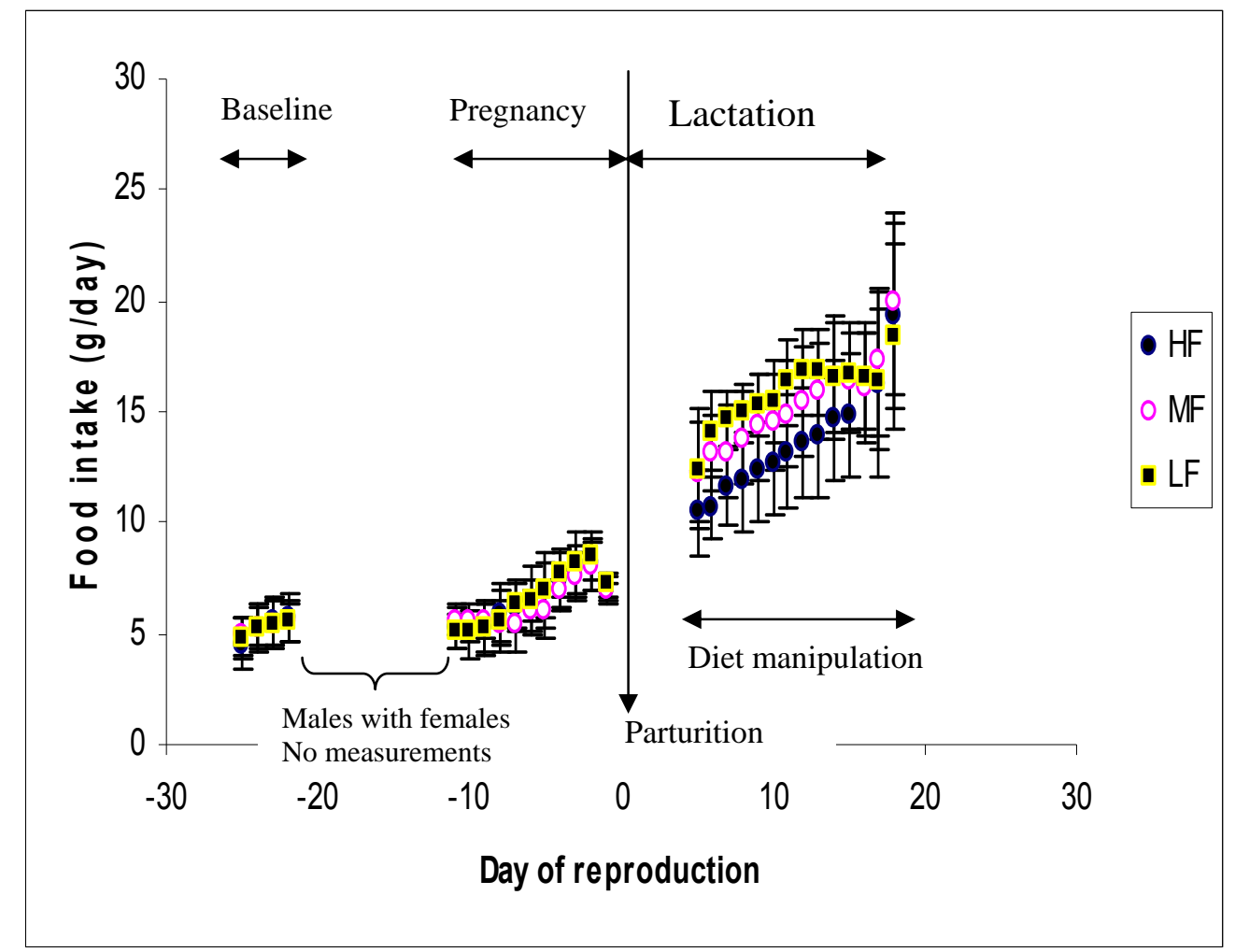

Figure 2: Mean daily food intake of female mice throughout baseline, pregnancy and lactation. Day 0 was parturition. Diet manipulation started on day 4 of lactation. Maternal food intake was measured between days 5-18 of lactation. Lactating mice were fed high fat (HF), medium fat (MF), and low fat (LF) diets. Error bars represent $1 \mathrm{sd}$ of the mean.

Doubly labelled water measurements: daily energy expenditure and total water turnover of lactating mice

The daily energy expenditure (DEE) measured on day 16 of lactation was not significantly different (ANOVA: $F_{2,49}=2.62, P>0.05$ ) between lactating mice fed on HF, MF and LF diets and averaged $103.30 \pm 12.64$ $\mathrm{kJ}$ day (range 78.09-131.71 $\mathrm{kJday}^{-1}, \mathrm{~N}=19$ ), 111.21 $\pm 9.71 \mathrm{~kJ}^{-1 a y}{ }^{-1}$ (range 91.45-123.07 $\mathrm{kJday}^{-1}$, $\mathrm{N}=19$ ) and 102.11 $\pm 14.29 \mathrm{~kJ}$ day (range 75.44-127.90 $\mathrm{kJday}^{-1}, \mathrm{~N}=18$ ), respectively (Table.2).
The total water turnover $\left(\mathrm{rH}_{2} \mathrm{O}\right)$ of lactating females fed on MF diet, HF diet and lactating controls fed on LF diet averaged 23.59 $\pm 6.26 \mathrm{~g} \mathrm{day}^{-1}$ (range 10.36-31.56 $\mathrm{g} \mathrm{day}^{-1}, \mathrm{~N}=19$ ), $24.12 \pm 588 \mathrm{~g}_{\text {day }}{ }^{-1}$ (range 13.41-31.53 g day $\left.{ }^{-1}, \mathrm{~N}=19\right)$ and 26.76 $\pm 6.58 \mathrm{~g}_{\text {day }}{ }^{-1}$ (range 17.15-46.31 $\mathrm{g} \mathrm{day}^{-1}, \mathrm{~N}=18$ ), respectively (Table 3.2). Comparison of the DEE of lactating females in the three dietary groups using body mass as a covariate showed significant (GLM: $F_{2,48}=319, P=0.047$ ) diet effect (Figure 3.14). 


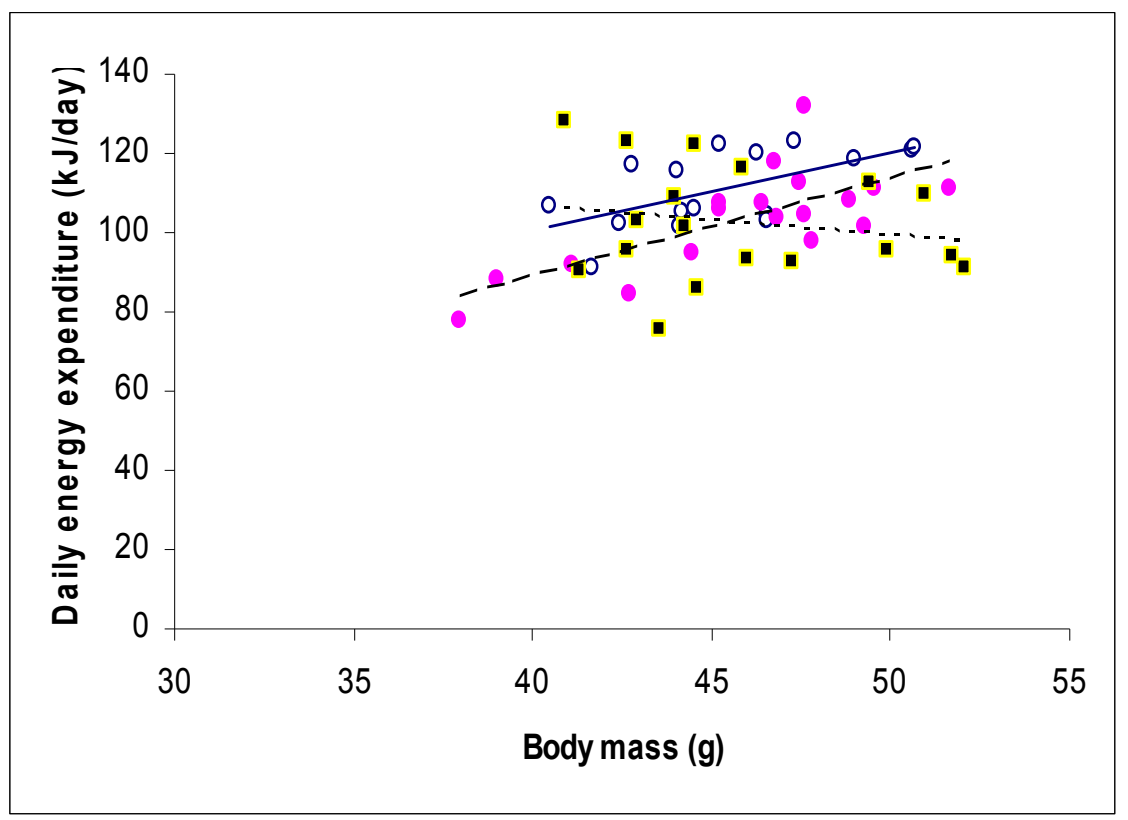

Figure 3: Daily energy expenditure as a function of body mass for lactating females fed on HF diet (filled circles, $y=2.53 x-$ 12.73, $r^{2}=0.534, N=19$ ), MF diet (open circles, $y=1.99 x+20.69, r^{2}=0.379, N=19$ ), and control females fed on LF diet (square symbols, $\left.y=-0.74 x+136.12, r^{2}=0.034, N=18\right)$.

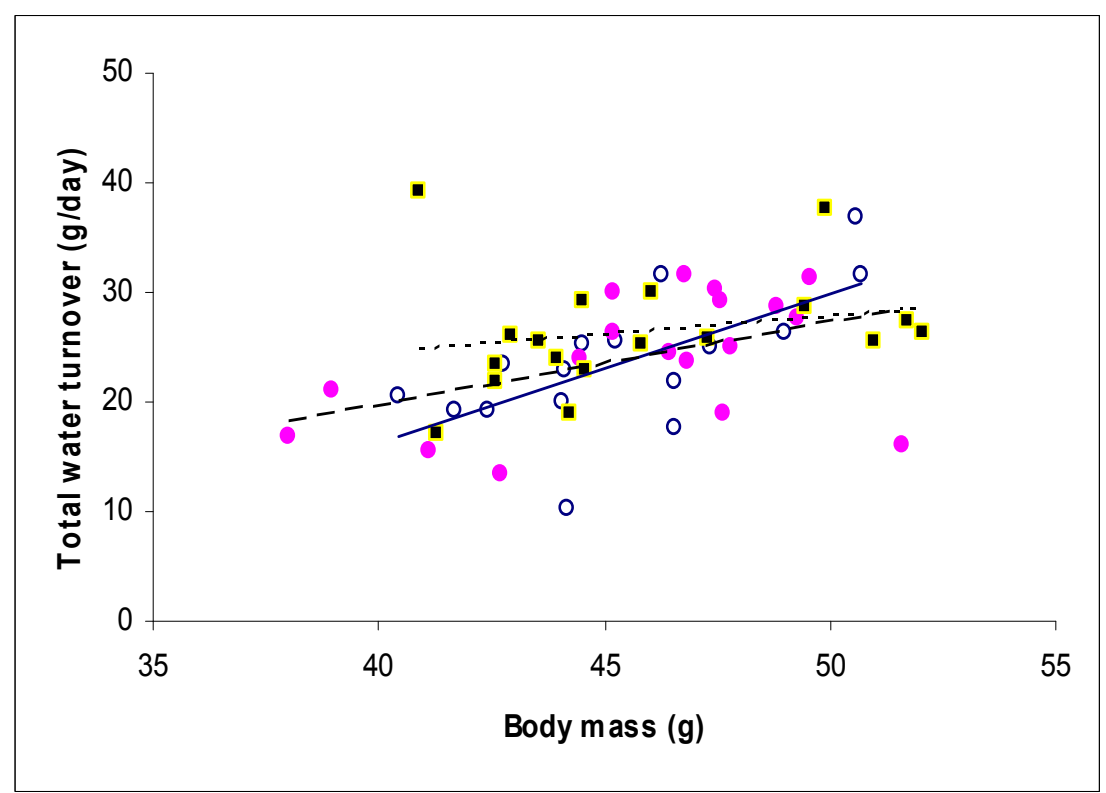

Figure 4: Total water turnover $\left(\mathrm{rH}_{2} \mathrm{O}\right)$ as a function of body mass for lactating females fed on $\mathrm{HF}$ diet (filled circles, $\mathrm{y}=0.76 \mathrm{x}$ $-10.91, r^{2}=0.224, N=19$ ), MF diet (open circles, $y=1.37 x-38.76, r^{2}=0.433, N=19$ ), and control females fed on $L F$ diet (square symbols, $\left.y=0.34 x+10.81, r^{2}=0.049, N=18\right)$. 
Table 2: Results of the DLW measurements of energy expenditure and water turnover in lactating $H F(N=19)$, $M F$ females $(\mathrm{N}=19)$ and lactating controls fed on LF diet $(\mathrm{N}=18)$.

\begin{tabular}{llllll}
\hline \multirow{2}{*}{ Trait } & \multicolumn{3}{c}{ Lactating mice } & \multicolumn{3}{c}{ ANOVA } \\
\cline { 2 - 6 } & HF females & MF females & LF females & $\mathrm{F}_{2,49}$ & $P$ \\
\hline $\mathrm{BM}(\mathrm{g})^{\mathrm{a}}$ & $45.85 \pm 3.65$ & $45.41 \pm 3.00$ & $45.80 \pm 3.59$ & 0.09 & 0.918 \\
\hline $\mathrm{k}_{\mathrm{d}}\left(\mathrm{h}^{-1}\right)^{\mathrm{b}}$ & $0.031 \pm 0.006$ & $0.030 \pm 0.007$ & $0.035 \pm 0.009$ & 1.53 & 0.227 \\
\hline $\mathrm{k}_{\mathrm{o}}\left(\mathrm{h}^{-1}\right)^{\mathrm{c}}$ & $0.041 \pm 0.006$ & $0.041 \pm 0.007$ & $0.047 \pm 0.009$ & 3.16 & 0.051 \\
\hline $\mathrm{k}_{\mathrm{o}} / \mathrm{k}_{\mathrm{d}}$ & $1.330 \pm 0.072$ & $1.368 \pm 0.111$ & $1.364 \pm 0.067$ & 1.07 & 0.349 \\
\hline $\mathrm{N}_{\mathrm{d}}(\% \text { of BM })^{\mathrm{d}}$ & $72.006 \pm 3.006$ & $72.378 \pm 2.195$ & $71.336 \pm 2.593$ & 0.69 & 0.509 \\
\hline $\mathrm{N}_{\mathrm{o}}(\% \text { of BM})^{\mathrm{d}}$ & $68.624 \pm 2.703$ & $68.907 \pm 2.363$ & $68.269 \pm 2.333$ & 0.28 & 0.754 \\
\hline $\mathrm{N}_{\mathrm{d}} / \mathrm{N}_{\mathrm{o}}$ & $1.049 \pm 0.011$ & $1.050 \pm 0.012$ & $1.045 \pm 0.011$ & 1.07 & 0.351 \\
\hline $\mathrm{DEE}\left(\mathrm{kJ} \mathrm{day}^{-1}\right)^{\mathrm{e}}$ & $103.30 \pm 12.64$ & $111.21 \pm 9.71$ & $102.11 \pm 14.29$ & 2.62 & 0.083 \\
\hline $\mathrm{rH}_{2} \mathrm{O}\left(\mathrm{g} \mathrm{day}^{-1}\right)^{\mathrm{f}}$ & $24.129 \pm 5.889$ & $23.594 \pm 6.266$ & $26.76 \pm 6.58$ & 1.29 & 0.285 \\
\hline
\end{tabular}

Values are means \pm S.D.

${ }^{a}$ Body mass before injection; ${ }^{b}$ deuterium elimination rate; ${ }^{c 18} \mathrm{O}$ elimination rate; ${ }^{d}$ deuterium $\left(\mathrm{N}_{\mathrm{d}}\right)$ and ${ }^{18} \mathrm{O}\left(\mathrm{N}_{\mathrm{o}}\right)$ dilution spaces (moles) were converted to $\mathrm{g}$ assuming a molecular mass of body water 18.02 and were expressed as percentage of body mass before injection; ${ }^{\mathrm{e}}$ daily energy expenditure; ' ${ }^{\mathrm{f}}$ total water turnover.

\section{Milk energy output}

The milk energy output (MEO) calculated on day 16 of lactation was significantly different (ANOVA: $F_{2}$, ${ }_{49}=11.64, P<0.001$ ) between lactating females fed on $\mathrm{HF}$, MF diets and LF diets and averaged $203.20 \pm 49.92$ kJ day ${ }^{-1}$ (range 77.69-312.28 $\mathrm{kJday}^{-1}, \mathrm{~N}=19$ ), $229.30 \pm 42.21 \mathrm{~kJ}^{-1 a y^{-1}}$ (range 149.45-271.84 $\mathrm{kJday}^{-1}$, $\mathrm{N}=19$ ) and $164.60 \pm 30.59 \mathrm{~kJ}$ day (range 101.77-215.59 $\left.\mathrm{kJday}^{-1}, \quad \mathrm{~N}=18\right), \quad$ respectively. Tukey pairwise comparisons among levels of diet indicate that MEO of both MF and HF mice were significantly higher $(P<0.05)$ than that of LF mice. The MEO of MF mice was not significantly different $(P>0.05)$ from that of HF mice. The relationship between growth of litters from $\mathrm{HF}, \mathrm{MF}$ and LF females and MEO showed a highly significant effect of MEO on litter growth (GLM: $\mathrm{F}_{2,48}=49.74, \mathrm{P}<0.001$ ) as well as a highly significant effect of the group (GLM: $F$ $2,48=13.66, \mathrm{P}<0.001$ ).

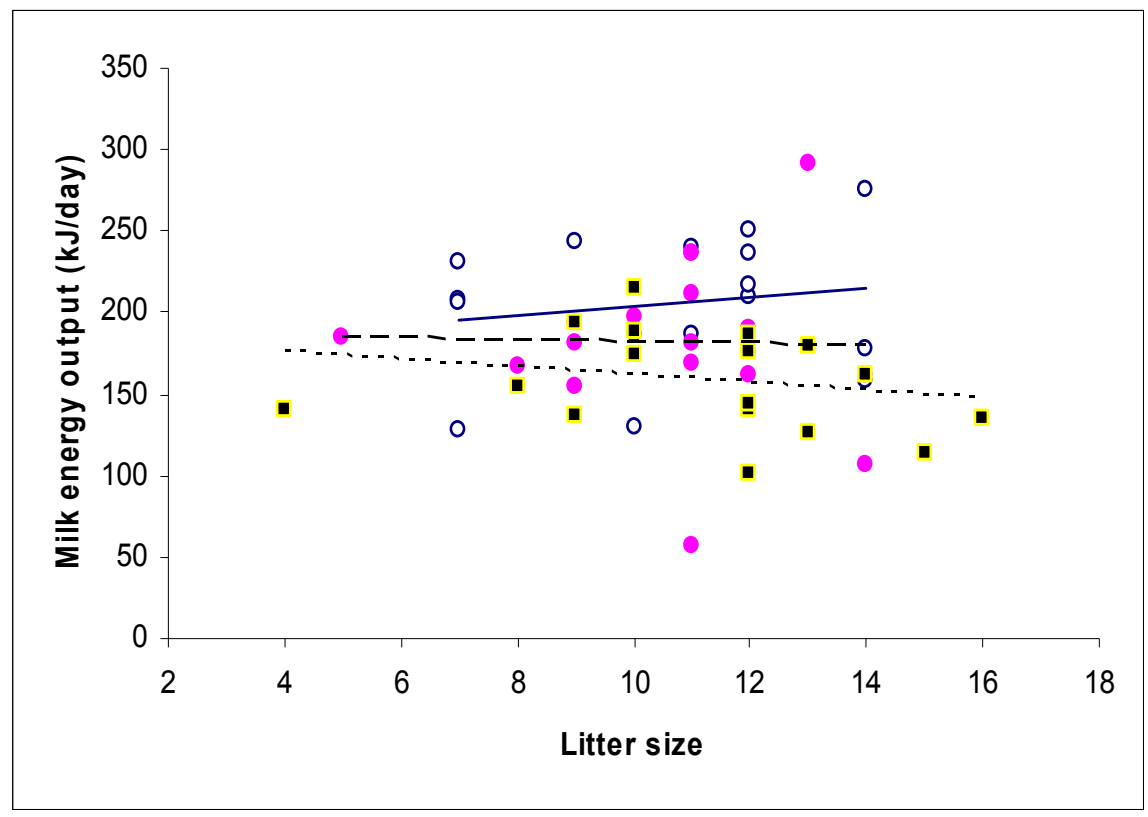

Figure 5: Milk energy output as a function of litter size for lactating females fed on HF diet (filled circles, $y=-0.52 x+$ 186.67, $r^{2}=0.001, N=19$ ), MF diet (open circles, $y=2.98 x+173.75, r^{2}=0.033, N=19$ ), and control females fed on LF diet (square symbols, $\left.y=-2.48 x+186.43, r^{2}=0.051, N=18\right)$. 


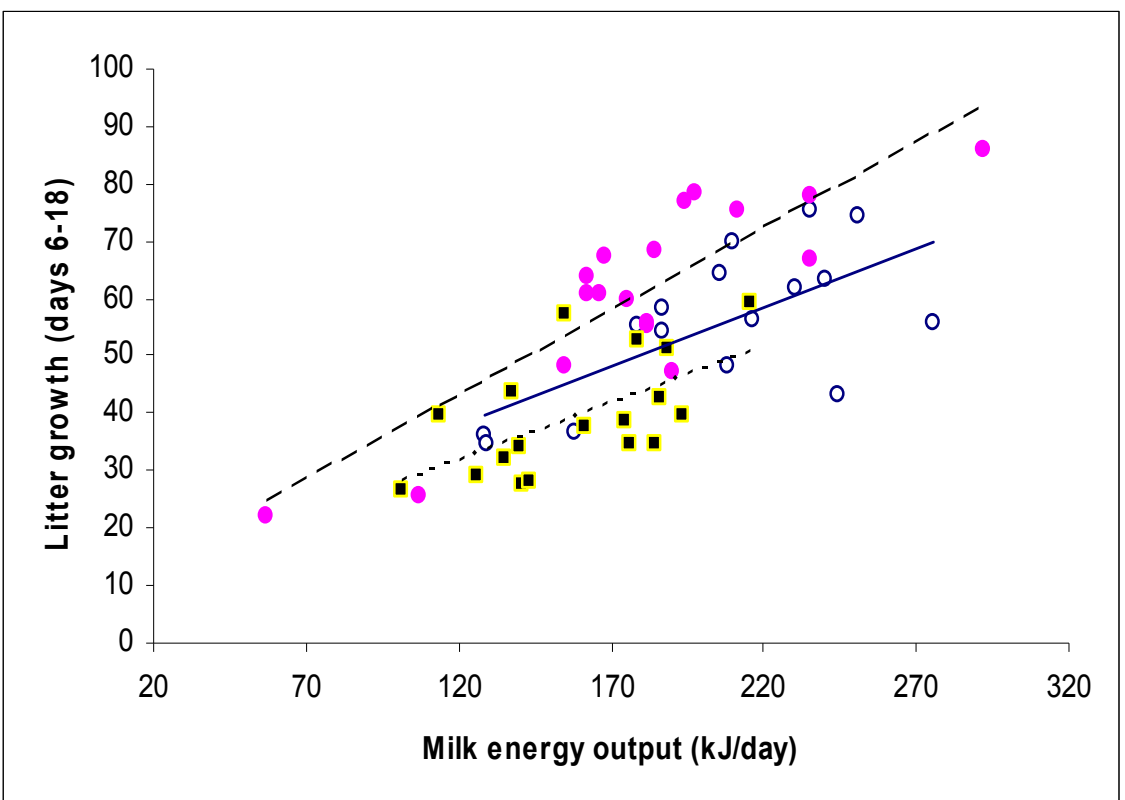

Figure 6: Litter growth as a function of milk energy output for lactating females fed on HF diet (filled circles, $y=0.29 x+765$, $r^{2}=0.737, N=19$ ), MF diet (open circles, $y=0.20 x+13.78, r^{2}=0.437, N=19$ ), and control females fed on LF diet (square symbols, $\left.y=0.19 x+8.14, r^{2}=0.362, N=18\right)$.

\section{DISCUSSION}

The body masses of female mice increased significantly during pregnancy. During lactation, HF and MF-fed females increased in body mass. This was associated with high energy intake by the mice. Contrary to previous studies (Hammond and Diamond, 1994; Speakman and McQueenie, 1996), the MF1 mice studied by Johnson et al., (2001a) and those used for the present study did not continue to increase their food intake until the end of lactation, but instead reached plateau from days 12 to 17 , respectively. The energy demand of the pups was probably still increasing at these levels because they were growing but there was no corresponding increase in maternal food and energy intakes, indicating that they were limited. In the previous study (Johnson et al., 2001a), the asymptotic daily food intake of MF1 mice was $23.1 \mathrm{~g} \mathrm{day}^{-1}$ and the corresponding net energy intake was $301 \mathrm{~kJ} \mathrm{day}^{-1}$. In the present study, the asymptotic daily food intake's corresponding gross energy and net energy intakes, litter mass at day 18 and milk production of HF and MFfed mice were significantly higher than that of the LF-fed mice. The feeding of fat to lactating mice impacted positively on reproductive performance. These positive effects occurred because the HF and MF-fed mice consumed more energy at peak lactation so the energy available for milk production was greatly increased. As a result, pups from mothers fed HF and MF diets were heavier at weaning than those from LF-fed mice. Dietary fat elevates milk fat concentration in sows and promotes faster growth in piglets throughout lactation (Averette et al., 1999). Increasing the fat content in the milk increases the energy supply to offspring thereby improving survival (Pettigrew, 1981) and pup growth rate. This suggests that the fat intake of lactating mice is correlated with the growth of their pups (Rolls et al., 1984; Loh et al., 2002). In this study, the faster growth rate of the pups from HF and MF-fed females was associated with the high energy exported as milk to the pups. This corroborates the findings of Grigor and
Warren (1980), Pettigrew (1981), Averette et al. (1999), Del Prado et al. (1997) and Loh et al. (2002) that increasing the fat content in milk increases the energy supply to offspring, thereby improving their survival and growth rate. This is consistent with the idea that energy is the most important limiting factor during lactation (Hanwell and Peaker, 1977; Oftedal, 1984; Kenagy et al., 1990; Speakman et al., 2001).

The difference in the SDA of the LF diet $(6.1 \%)$, HF $(4.5 \%)$ and MF $(3.9 \%)$ diets was $1.6 \%$ and $2.2 \%$ (Kagya-Agyemang, 2008), yet the effects of feeding HF and MF diets to lactating females were greater than on LF diet. This shows that other factors were involved in the delivery of energy to the offspring.

There are several possible explanations for the results presented here. During lactation, metabolic heat production is increased because of the grater food intake and milk production, which is a highly exothermic process (Adels and Leon, 1986; Król and Speakman, 2003a, b; Król et al, 2007). Again, fatty acids are the major form in which fat is made available as fuel for energy generation. The main ways by which lactating mice can increase the fat content of their milk to support the faster growth of their offspring is through increased dietary fat intake and increased de novo lipogenesis. At weaning, litters from $\mathrm{HF}$ and MF-fed mice were significantly heavier than pups on LF diet. This was evidenced by the fact that the HF and MF-fed mice not only consumed more energy at peak lactation but also delivered more milk energy to their pups than the LF-fed mice. Probably, the ability of the HF and MF-fed mice to directly transfer absorbed fat into the milk might have reduced the heat production of lactogenesis.

The main processes that contribute to increased heat load on the animal at peak lactation are digestion and milk production. This finding is supported by the observation that high dietary fat intake could result in the "loss" of metabolic heat production due to the strong suppressive effect of high fat diets on lipogenesis in adipose tissue (Mercer and Trayhurn, 1984). 
In the present study, the LF diet contained $70 \%$ energy as carbohydrate. Conversion of carbohydrate to fat prior to oxidation is thermogenically costly and about $28 \%$ of the energy content of carbohydrate is lost as heat (Flatt, 1978; Hellerstein et al., 1996; Hellerstein, 1999). This indicates that the LF-fed mice had to expend part of energy consumed for de novo lipogenesis to produce enough milk to support the growth of their offspring. Overall, the growth of offspring from HF and MF-fed mothers was better when compared with that of LF-fed mice. This shows that offspring growth improved on the HF and MF diets.

A major feature of this study is that despite the differences in digestible energy intake at peak lactation, the mice in the different dietary treatments did not show significant differences in body mass and the overall DEE did not differ between the three diets. This indicates that the positive effects of HF and MF diets on lactation performance were due to the ability of the HF and MFfed mice to reduce the metabolic heat generated as a by-product of milk production. It is well established that feeding rats on a high fat diet depresses the rate of mammary gland lipogenesis (Agius and Williams, 1980; Gregor and Warren, 1980). Thus, at peak lactation the $\mathrm{HF}$ and MF-fed mice assimilated more energy than the LF-fed mice and used the extra energy to generate more milk to support the faster growth of their offspring.

\section{CONCLUSION}

In summary, MF1 mice fed HF, MF, and LF diets reached an asymptote in their daily food intake at $14.95 \pm 1.14 \mathrm{~g} \mathrm{day}^{-1}, 16.30 \pm 0.61 \mathrm{~g} \mathrm{day}^{-1}$ and $16.57 \pm$ $0.26 \mathrm{~g} \mathrm{day}^{-1}$ at peak lactation. At weaning, the pups from $\mathrm{HF}$ and MF-fed mothers were significantly heavier than pups from LF-fed mice. This was because the peak lactation energy intake of $\mathrm{HF}$ and MF-fed mice was significantly higher than LF-fed mice. The positive effects of feeding fat to mice were in part due to the low SDA and probably low heat production for milk synthesis.

\section{ACKNOWLEDGEMENTS}

We thank Shona Fleming and Duncan Wood for animal husbandry, Peter Thompson and Dr Paula Redman for assistance with isotope analysis and David Brown and Christine Horrocks for help with bomb calorimetry. This experiment was authorized by a local ethical review committee and carried out under United Kingdom Home Office project licence PPL 60/2881.

\section{REFERENCES}

Adels, L. E. and Leon, M., 1986. Thermal control of mother-young contact in Norway rats: factors mediating the chronic elevation of maternal temperature. Physiol. Behav. 36: 183-196.

Agius, L. Y. and Williams, D. H., 1980. Rapid inhibition of lipogenesis in vivo in lactating rat mammary gland by medium chain triacylglycerols and partial reversal by insulin. Biochem. J. 192: 361364.
Averette, L. A., Odle, J., Monaco, M. H. and Donovan,

S. M., 1999. Dietary fat during pregnancy and lactation increases milk fat and insulin-like growth factor I concentrations and improves neonatal growth rates in swine. J. Nutr. 129:2123-2129.

Bacigalupe, L. D. and Bozinovic, F., 2002. Design, limitations and sustained metabolic rate: lessons from small mammals. J. Exp. Biol. 205: 29632970.

Bozinovic, F. and Rosenmann, M., 1989. Maximum metabolic rate of rodents- physiological and ecological consequences on distributional limits. Funct. Ecol. 3: 173-181.

Coward, W. A. and Prentice, A. M., 1985. Isotope method for the measurement of carbon dioxide production rate in man. Am. J. Clin. Nutr. 41: 659-661.

Del Prado, M., Delgado, G. and Villalpando, S., 1997. Maternal lipid intake during pregnancy and lactation alters milk composition, production and litter growth in rats. J. Nutr. 127: 458-462.

Flat, J. P., 1978.. The biochemistry of energy expenditure. Rec. Adv. Obesity Res. 2:211-217.

Gawecki, J. and Jeszka, J., 1978. The effect of the extent of hydrolysis on casein on its specific dynamic action in the rat. Br. J. Nutr. 40: 465471.

Grigor, M. R. and Warren, S. M., 1980. Dietary regulation of mammary lipogenesis in lactating rats. Biochem. J. 188: 61-65.

Hellerstein, M. K., Schwarz, J. M. and Neese, R. A., 1996. Regulation of hepatic de novo lipogenesis in humans. Ann. Rev. Nutr. 16:523-557.

Hellerstein, M. K., 1999. De novo lipogenesis in humans: metabolic and regulatory aspects. Eur. J. Clin. Nutr. 53: S53-S65.

Hammond, K. A, and Diamond J., 1994. Limits to dietary nutrient intake and intestinal nutrient uptake in lactating mice. Physiol. Zool. 67 (1): 282-303.

Hammond, K. A, and Diamond, J., 1997. Maximal sustained energy budgets in humans and animals. Nutr. 386: 457-462.

Hammond, K. A, Lloyd, K. C. K, and Diamond J., 1996. Is mammary output capacity limiting to lactational performance in mice? J. Exp. Biol. 199: 337-349.

Hammond, K. A, and Kristan D. M., 2000. Responses to lactation and cold exposure by deer mice, Peromyscus maniculatus. Physiol. Biochem. Zool.73: 547-556.

Hanwell, A. and Peaker, M., 1977. Physiological effects of lactation on the mother. Symp. Zool. Soc. Lond. 41:297-312. 
Johnson, M. S, Thomson S.C, and Speakman J. R., 2001a. Limits to sustained energy intake I. Lactation in the laboratory mouse, Mus musculus. J.Exp. Biol. 204: 1925-1935.

Johnson, M. S, Thomson S. C, and Speakman J. R., 2001b. Limits to sustained energy intake III. Effect of concurrent pregnancy and lactation in Mus musculus. J. Exp. Biol. 204: 1947-1956.

Johnson, M. S. and Speakman, J. R., 2001c. Limits to sustained energy intake V. Effect of cold exposure during lactation in Mus musculus. J. Exp. Biol. 204: 1967-1977.

Kagya-Agyemang, J. K., 2008. Limits to sustained energy intake during lactation: effects of macronutrient composition. PhD thesis. University of Aberdeen, Scotland, United Kingdom. Pp 36-134.

Kenegy, G. J., Masman, D., Sharbaugh, S. M. and Nagy, K. A., 1990. Energy expenditure during lactation in relation to litter size in free-living goldenmantled ground squirrels. J. Anim. Eco. 59: 7388.

Kriss, M., Forbes, E. B. and Miller, R. C., 1934. The specific dynamic effects of protein, fat, and carbohydrate as determined with the albino rat at different planes of nutrition. J. Nutr. 8: 509534.

Król, E, and Speakman J. R., 1999. Isotope dilution spaces of mice injected simultaneously with deuterium, tritium and oxygen-18. J. Exp. Biol. 202: 2839-2849.

Król, E, and Speakman J. R., 2003a. Limits to sustained energy intake. VI. Energetics of lactation in laboratory mice at thermoneutrality. J. Exp.Biol. 206: 4255-4266.

Król, E, and Speakman J. R., 2003b. Limits to sustained energy intake. VII. Milk energy output in laboratory mice at thermoneutrality. J. Exp.Biol. 206: 4267-4281.

Król, E, Murphy, M. and Speakman, J. R., 2007. Limits to sustained energy intake. X. Effects of fur removal on reproductive performance in laboratory mice. J. Exp.Biol. 210: 4233-4243.

Loh, T. C., Foo, H. L., Zurina, A. W. and Tan, B. K., 2002. Effect of feeding fat during pregnancy and lactation on growth performance, milk composition and very low density lipoprotein composition in rats. Mal. J. Nutr. 8(2): 125-135.

Mercer, S. W. and Trayhurn, P., 1984. Effects of high fat diet on the thermogenic activity of brown adipose tissue in cold-acclimated mice. J.Nutr. 114: 1151-1158.
Nagy, K. A., 1975. Water and energy budgets of freeliving animals: measurements using isotopically labelled water. In Environmental Physiology of Desert Organisms (ed. N. F. Hadley), pp.227245.Strousdburg, PA: Dowden, Hutchinson and Ross.

Nagy, K. A. and Costa, D. P., 1980. Water flux in animals: analysis of potential errors in the tritiated water method: Am. J. Physiol. 238: R454-R465.

Nagy, K. A., 1983. The Doubly Labelled Water $\left({ }^{3} \mathrm{HH}^{18} \mathrm{O}\right)$ Method: A Guide to its Use. UCLA Publication no.12-1417. Los Angeles, CA: University of California.

Oftedal, O. T., 1984. Milk composition, milk yield and energy output at peak lactation: a comparative review. Symp.Zool.Soc. Lond. 51: 33-85.

Pettigrew, J. E., 1981. Supplemental dietary fat for peripartal sows: a review. J. Anim. Sci. 53: 107117.

Rolls, J. B., Van Duijvenvoorde, P. M. and Rowe, E. A., 1984. Effects of diet and obesity on body weight regulation during pregnancy and lactation in the rat. Physiol. Behav. 32: 161-168.

Ryan, B. F., Joiner, B. L. and Ryan T. A., Jr., 1985. Minitab Handbook. $2^{\text {nd }}$ edition. Boston, MA: PWs-Kent.

Speakman, J. R., Nagy, K. A., Masman, D., Mook, W. G., Poppit, S. D., Strathearn, G. E. and Racey, P. A., 1990. Interlaboratory comparison of different analytical techniques for the determination of oxygen-18 abundance. Anal. Chem. 62: 703-708.

Speakman, J. R, and McQueenie, J., 1996. Limits to sustained metabolic rate: The link between food intake, basal metabolic rate and morphology in reproducing mice, Mus musculus. Physiol. Zool. 69: 746-769.

Speakman, J. R., 1997. Doubly Labelled Water: Theory and Practice. London: Chapman and Hall.

Speakman, J. R., 2000. The cost of living: Field metabolic rates of small mammals. Adv. Ecol. Res. 30: 177-297.

Speakman, J. R, Gidney A., Bett, J., Mitchell, I. P. and Johnson, M. S., 2001. Limits to sustained energy intake IV. Effect of variation in food quality on I acatating mice, Mus musculus. J. Exp. Biol. 204: 1957-1965.

Speakman, J. R. and Krol, E., 2005a. Limits to sustained energy intake IX: a review of hypotheses. J. Comp. Physiol. B 175: 375-394. 
Stenseth, N. C., Framstead, E., Migula, P., Trojan, P. and Wojciechowska-Trojan, B., 1980. Energy models for the common vole (Microtus arvalis): energy as a limiting resource for reproductive output. Oikos 34: 1-22.
Weir, J. B. de V., 1949. New methods for calculating metabolic rates with special reference to protein metabolism. J. Physiol. Lond. 109: 1-9. 